\title{
Screening of Keratinolytic Bacteria from Poultry Wastes
}

\author{
Z. Jahan, S. N. Khan* and M. Mozammel Hoq \\ Department of Microbiology, University of Dhaka, Dhaka 1000
}

\begin{abstract}
The aim of this study was to characterize keratinolytic bacteria isolated from feather waste. Six isolates were recovered from poultry feather-decomposed materials. Isolate Z3 and Z4 showed important feather degrading activity when grown on basal medium containing $1 \%$ native feather as the only source of energy, carbon and nitrogen. All isolates were Gram positive and rod-shaped bacilli. Based on microscopic and biochemical analysis, the isolates were identified as Bacillus spp. Keratinolytic activities of these isolates were measured after cultivation of the bacteria on raw feathers. Maximum keratinase activity was showed by the isolate Z4 (22.3 U/ml) with the specific activity of $40.5 \mathrm{U} / \mathrm{mg}$. Bacillus sp. Z4 is a potent producer of keratinase, which can be used for production of the enzyme in large scale.
\end{abstract}

Key words: Identification, Purification, Characterization, Keratinase, Feather

\section{Introduction}

Feathers are produced in large amounts as a waste by-product in poultry plants, reaching millions of tones per year worldwide (Williams, et al., 1991). A current valueadded use for feather is the conversion to feather meal, a digestible dietary protein for animal feed, using physical and chemical treatments. However, feathers are currently utilized on a limited basis as a dietary protein supplement for animal feed because feather meal production is an expensive process, requiring significant amounts of energy. In addition, this process destroys certain amino acids, yielding a product with poor digestibility and variable nutrient quality (Papadopoulos et al., 1986).

Keratin is the insoluble structural protein of feathers and wool and is known for its high stability (Bradbury, 1973). The composition and molecular configuration of its constituent amino acids warrant structural rigidity. The keratin chain is tightly packed into a supercoiled polypeptide chain (Parry and North, 1998), resulting in mechanical stability. In addition, cross-linking of protein chains by cysteine bridges confers high mechanical stability and resistance to proteolytic degradation of keratins. Nevertheless, feathers do not accumulate in nature, since structural keratin can be degraded by some microorganisms (Onifade et al., 1998). Reduction of cysteine bridges may significantly influence

\footnotetext{
* Corresponding author: E-mail: shakilamanjur@yahoo.com
}

keratin degradation (Noval and Nickerson, 1959; Kunert and Stansky, 1988).

Keratinolytic proteases offer considerable opportunities for a low energy consuming technology for bioconversion of poultry feathers from a potent pollutant to a nutritionally upgraded protein feed staff for live stock. Keratinases have got a particular role in dehairing of hairs from the skin (Mukhopadhyay and Chandra, 1990 Letourneau et al., 1998). The alkaline protease preparation with keratinase has a potential application in leather manufacture. Since, keratinases could be of also interesting for the pharmaceuticals, cosmetics and leather industries, it is worth to search for potential microorganisms producing these enzymes. Known keratinases are mainly produced by mesophilic fungi and actinomycetes (Noval and Nickerson, 1959; Kushwaha 1983; Bockle et al., 1995; Santos et al., 1996), but some thermophilic species of Bacillus produce feather-degrading enzymes (Williams et al., 1990; Kim et al., 2001). Bacillus sp. has special advantages due to their ability to secrete large amounts of protein directly into the medium (Hardwood, 1992). Among them, B. licheniformis strains appear to be potential candidates for industrial enzyme production (Hoq et al., 2005). 
In this report, we describe the isolation and characterization of mesophilic microorganisms showing keratinolytic activity from poultry. Such microorganisms will be less energyconsuming than the thermophilic strains usually used in feather processing.

\section{Materials and Methods}

\section{Isolation and screening of keratinolytic microorganisms}

For isolation of keratinolytic microorganisms, samples were collected from feather decomposed materials of two poultry farms at Savar, Dhaka, Bangladesh. Strong selective conditions were created, using an enrichment medium or containing chicken feathers as the only source of carbon and nitrogen as described in Hoq et al., (2005). One gram of the sample was added to a primary enrichment flask (500 ml capacity) containing $50 \mathrm{ml}$ of enrichment medium and was incubated at $37^{\circ} \mathrm{C}$ in an orbital shaker for 7 days. One $\mathrm{ml}$ of broth was taken from the primary enrichment flask, re-inoculated into $50 \mathrm{ml}$ of fresh enrichment medium, and cultivated under the same conditions until the turbidity became noticeable due to the bacterial growth. The same procedure was repeated for a third time. This final broth was filtered through sterilized filter paper to remove solid particles and dispersed into plastic test tubes. Suitably diluted culture sample was spread on nutrient agar plates (Cappuccino and Sherman, 1996). The plates were incubated at $37^{\circ} \mathrm{C}$. The cultural characteristics of the isolated colonies were then studied.

\section{Identification of the isolates}

In order to identify the isolates, the microscopic examination (Gram staining) and seven biochemical tests viz. catalase test, oxidase test, carbohydrate fermentation test, methyl red (MR) test, voges proskauer (V.P.) test, indole production test, nitrate reduction test (according to the Bergey's Manual of Systemic Bacteriology, 9th edition) were performed.

\section{Physical change of feather after enzymatic digestion}

Keratinolytic organism was cultured in nutrient broth for 7$8 \mathrm{~h}$. Then it was transferred to test tube containing liquid basal medium ( $0.5 \mathrm{~g} \mathrm{NaCl} \mathrm{l}^{-1}, 0.3 \mathrm{~g} \mathrm{~K}_{2} \mathrm{HPO}_{4} \mathrm{l}^{-1}$, $0.4 \mathrm{~g}$ $\mathrm{KH}_{2} \mathrm{PO}_{4} \mathrm{l}^{-1}$ ) (Riffel et al., 2003) where whole feather was added as the sole source of carbon and nitrogen. The test tube was then incubated in shaking incubator for 24, 48 and
$72 \mathrm{~h}$. A negative control was also prepared where no bacteria were inoculated.

\section{Production of keratinolytic enzymes}

Each of the bacterial isolate was cultivated in $100 \mathrm{ml}$ Feather Meal Broth medium in a 500-ml Erlenmeyer flask at $37^{\circ} \mathrm{C}$ under shaking $(150 \mathrm{rpm})$ in a thermostated water bath for 72 h. Cultivation was done with $5 \mathrm{ml}$ of 7-8 h grown inoculum (in nutrient broth) of the respective bacterial cultures. The samples were withdrawn and centrifuged at $5000 \mathrm{rpm}$ for 20 min at 24, 48 and $72 \mathrm{~h}$. The supernatants were preserved at $4^{\circ} \mathrm{C}$ and assayed for protein.

\section{Determination of keratinase activity}

Azocasein hydrolysis was used as an alternative to the azokeratin hydrolysis. Keratinolytic protease activity was determined with azocasein (Sigma Co. St. Louis. Mo.) as a substrate by a modified procedure described by Kregler and Lockwood (1981). In brief, $200 \mu \mathrm{l}$ of $1 \%$ azocasein solution in $0.05 \mathrm{M}$ Tris -HCI buffer at $\mathrm{pH} 8.5$ was incubated with 400 $\mu \mathrm{l}$ crude enzyme solution for $30 \mathrm{~min}$ at $37^{\circ} \mathrm{C}$ in a water bath with shaking. The reaction was terminated by addition of 1.4 $\mathrm{ml}$ of $10 \%$ trichloroacetic acid (TCA). After $15 \mathrm{~min}$ at $4^{\circ} \mathrm{C}$, the reaction mixture was centrifuged at $10,000 \mathrm{xg}$ for $10 \mathrm{~min}$. One ml supernatant was mixed with $1 \mathrm{ml}$ of $0.5 \mathrm{~N} \mathrm{NaOH}$ and the absorbance was read at $440 \mathrm{~nm}$. The control was treated in the same way, except TCA was added before the addition of crude enzyme. One unit of caseinolytic activity was determined as the amount of enzyme that produces an increase in absorbance of 0.01 per min under the assay conditions. The soluble protein concentration in the culture supernatant was estimated according to the Bradford method (Bradford, 1976).

\section{Results and Discussion}

A screening program was employed to obtain bacterial isolates capable of producing feather degrading extracellular keratinase enzyme using feather (keratin) as sole carbon substrate. The potential isolates were then characterized and identified to its genus level. In this regard, samples were collected from various soil habitats and the feather pieces that were degraded in the aforementioned soil samples were inoculated into basal medium (the selective medium for Bacillus) containing $1 \%$ ground feather as a sole carbon 
source and incubated at $37^{\circ} \mathrm{C}$ for the enrichment of feather degrading bacterial strains. A total of 6 isolates were obtained from 2 different habitats.

All isolates showed good growth with distinct characteristics on nutrient agar and turned nutrient broth turbid. Identification of bacteria was based on morphological, cultural and biochemical tests comparing the data with standard species (Hoq et al., 2005). Morphological and physiological characteristics of the bacteria were compared with the Bergey's Manual of Systemic Bacteriology. All isolates were Gram positive, rod shaped and spore-former and were able to utilize both glucose and sucrose but not lactose. They were also catalase positive, oxidase negative and MR-VP test negative. The organisms were unable to utilize citrate and all were able to reduce nitrate to nitrite. All isolates showed typical characteristics of Bacillus sp.

Reports of several workers showed that the Bacillus sp was considered as prime producer of keratinase (Lin et al.,1995). sp. showed good growth with a varying level of keratinolytic activity (Figure 1) on feather meal and the experiment was repeated for four times. The keratinolytic activity of all isolates increased with the increase of time however, the rates of increase of the enzyme activity were not similar in pattern for all the isolates. The highest activity was demonstrated by Z3 (20.4 U/ml) and Z4 (22.3 U/ml) as compared with reference strain MZK-05 (25.2 U/ml) (Hoq et al., 2005) after 72 $\mathrm{h}$ of cultivation on feather meal. These two strains were considered for further investigation as they showed maximum keratinolytic activity.

The soluble protein concentration of the Bacillus sp (Z3 and Z4) was estimated after $72 \mathrm{~h}$ fermentation in laboratory feather meal medium. From the standard curve of protein concentration Z3 showed a protein concentration of 0.51 $\mathrm{mg} / \mathrm{ml}$ and Z4 showed a protein concentration of $0.55 \mathrm{mg} / \mathrm{ml}$ when compared with the reference strain MZK-05 (0.64 $\mathrm{mg} / \mathrm{ml}$ ), (Fig. 2).



Fig. 1. Time course for the production of keratinase (by azocasein digest method).

All isolated Bacillus sp were grown in basal medium with or without feather meal or keratin powder as a sole source of carbon, nitrogen and sulphur at $37^{\circ} \mathrm{C}, \mathrm{pH}$ 7.5. The Bacillus
The enzyme assay revealed that Z3 exhibited specific activity of $40 \mathrm{U} / \mathrm{mg}$ whereas Z4 exhibited specific activity of 40.5 $\mathrm{U} / \mathrm{mg}$ as compared to a precisely isolated Bacillus sp 




Fig. 2: Protein profile and specific activity of most potential keratinolytic isolates (Z3 and Z4)

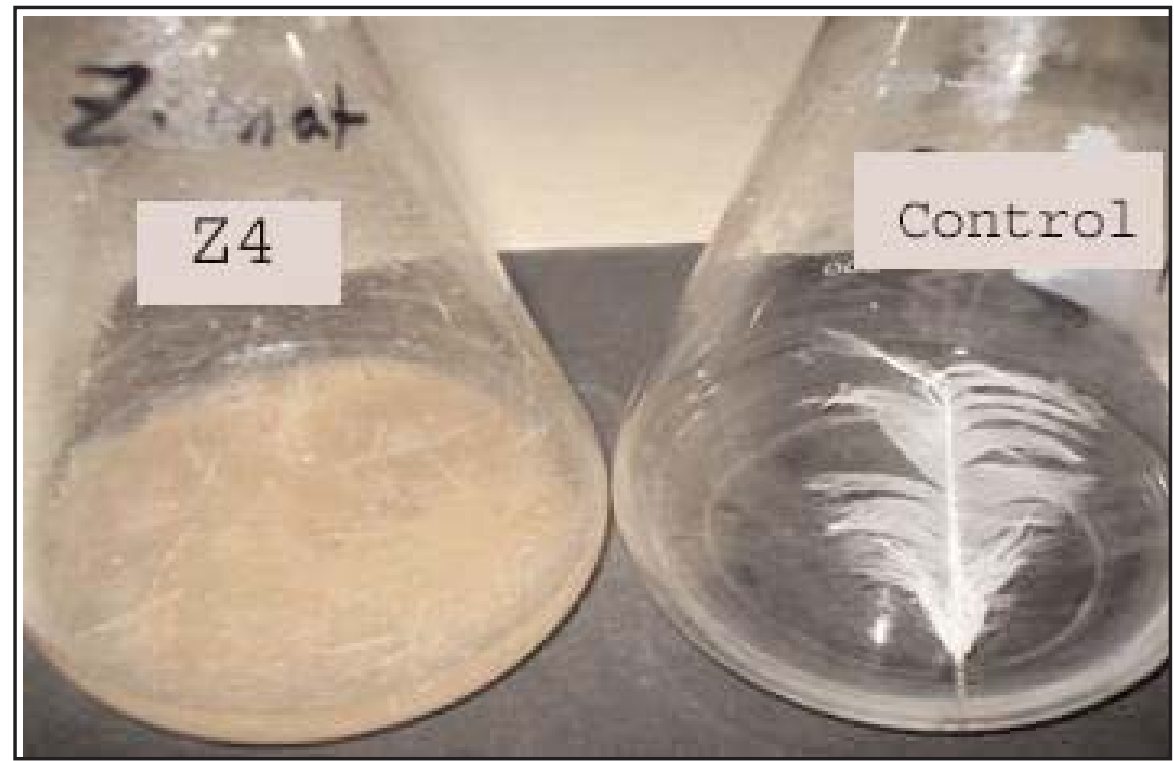

Fig. 3. A representative illustration of feather degradation by the most potent keratinolytic isolate Bacillus $\mathrm{Z} 4$

MZK-05 (Hoq et al., 2005) (Figure 2) which is $39.4 \mathrm{U} / \mathrm{mg}$.

In this study ground feather was used as keratin substrate which was prepared from feather. It is relatively easy to prepare the substrate from feather than from human hair, nails, cow's horn or sheep's wool. Microorganisms growing on medium containing feather meal as a unique carbon and nitrogen source presented variable activity on azokeratin, suggesting that this enzyme may be inducible. Substrate levels in the medium may regulate enzyme secretion.
A visible or qualitative determination of keratinase activity was done by cultivating the isolates in 1\% whole feather containing liquid basal medium at $37^{\circ} \mathrm{C}$ for 7 days. It was found that after 7 days, isolate Z3 and Z4 degraded chicken feathers completely including the shaft (Figure 3). Minor feather degradation was achieved by the other isolates (namely Z1, Z2, Z5 and Z6). 


\section{Conclusion}

In the present study, we isolated six Bacillus sp. capable of producing keratinase from habitats where keratin containing substrate is decomposed under natural conditions. Two isolates, Z3 and Z4, exhibited highest keratinase activities, and Z4 was the most potential isolate which degraded feather completely after 7 days at $37^{\circ} \mathrm{C}$. The keratinolytic microorganisms isolated in this study therefore could play an important role in production of animal feed protein in addition to the biodegradation of poultry wastes.

\section{References}

Bradbury J. H. (1973) The structure and chemistry of keratin fibers. Adv Prot Chem 67: 111-211

Böckle B., Galunski B. and Müller R. (1995) Characterization of a keratinolytic serine protease from Streptomyces pactum DSM40530. Appl Environ Microbiol. 61: 3705-3710

Bradford M. M. (1976) A rapid sensitive method for the quantitation of microgram quantities of protein dye binding. Anal. Biochem. 72: 680-685.

Cappuccino James G. and Sherman, Natalie (1996). Microbiology: A Laboratory Manual. 4th. s.l. : Addison-Wesley, p. 465.

Hardwood C. R. (1992) Bacillus subtilis and its relatives: Molecular biological and industrial workhouses. Trends Bitechnol. 10: 247-256.

Hoq M. M., Siddiquee Z. A. K., Kawasaki H. and Seki T. (2005) Keratinolytic activity of some newly isolated Bacillus species. J. Biol. Sci., 5(2): 193-200.

Kunert J. and Stransky Z. (1988) Thiosulfate production from cysteine by the keratinophilic prokatyote Streptomyces fradiae. Arch Microbiol . 150: 600-601.

Kushwaha R. K. S. (1983) The in vitro degradation of peacock feathers by some fungi. Mykosen. 26: 324-326.

Kim J. M., Lim W. J. and Suh H. J. (2001) Feather-degrading Bacillus species from poultry waste. Process Biochem. 37: 287-291.
Kregler A. and Lockwood D. (1981) Detection of extra cellular toxins produced by Vibrio vulnificus. Infect. Immun. 33: 583-590.

Letourneau F., Soussotte V., Bressoier P., Brandland P. and Verneuil B. (1998) Keratinolytic activity of Streptomyces sp. S.K-02: A new isolated strain. Lett. Applied Microbiol. 26: 77-80.

Lin X. Kelemen D. W., Miller E. S. and Shih J. C. H. (1995) Nucleotide sequence and expression of kerA, the gene encoding a keratinolytic protease of Bacillus licheniformis PWD-1. Appl. Environ. Microbiol. 61: 1469-1474.

Mukhopadhyay R. P. and Chandra A. L. (1990) Keratinase of a streptomycete. Indust.J. Expt. Biol. 28: 575-577.

Noval J. J.and Nickerson W. J. (1959) Decomposition of native keratin by Streptomyces fradiae. J Bacteriol. 77: 251-263.

Onifade A. A., Al-Sane N. A., Al-Musallam A. A.and AlZarban, S. (1998) Potentials for biotechnological applications of keratin-degrading microorganisms and their enzymes for nutritional improvement of feathers and other keratins as livestock feed resources. Biores Technol. 66: 1-11.

Papadopoulos M. C, El Boushy, A. R. Roodbeen, A. E. and Ketelaars, E. H. (1986) Effects of processing time and moisture content on amino acid composition and nitrogen characteristics of feather meal. Anim Feed Sci Technol . 14: 279-290.

Parry D. A. D and North A. C. T. (1998) Hard a-keratin intermediate filament chains: substructure of the $\mathrm{N}$-and $\mathrm{C}$ terminal domains and the predicted structure and function of the C-terminal domains of type I and type II chains. J Struct Biol. 122: 67-75.

Riffel A., Lucas F., Heeb P. and Brandelli A. (2003) Characterization of a new keratinolytic bacterium that completely degrades native feather keratin. Arch. Microbiol., 179(4): 258-265. 
Santos, R. M. D. Firmino, A. A. P. Sá, C. M. Felix, C. R (1996) Keratinolytic activity of Aspergillus fumigatus Fresenius. Curr Microbiol. 33: 364-370.

Williams, C. M. Richter, C.S. MacKenzie, J. M. Shih, J. C. H. (1990) Isolation, identification, and characterization of a feather-degrading bacterium. Appl Environ Microbiol. 56: 1509-1515.
Williams, C. M. Lee, C. G. Garlich and J. D. Shih, J. C. H. (1991) Evaluation of a bacterial feather fermentation product, feather-lysate, as a feed protein. Poultry Sci. 70: 85-94.

Received : June 04, 2009;

Accepted : November 09, 2009 